Research Article

\title{
Restoration of Citropsis articulata, a Species at Risk from Medicinal Overharvesting in a Ugandan Rainforest Reserve
}

\author{
William Olupot \\ Nature and Livelihoods, P.O. Box 21669, Kampala, Uganda \\ Correspondence should be addressed to William Olupot; wolupot@gmail.com
}

Received 24 June 2021; Accepted 4 September 2021; Published 21 September 2021

Academic Editor: Ahmad A. Omar

Copyright (c) 2021 William Olupot. This is an open access article distributed under the Creative Commons Attribution License, which permits unrestricted use, distribution, and reproduction in any medium, provided the original work is properly cited.

Citropsis articulata, the African cherry orange, is considered to be threatened in Ugandan forests as a result of its purported aphrodisiac properties. This study, part of an ongoing effort to address restoration needs of Mabira Central Forest Reserve in Uganda, demonstrates the feasibility of restoring depleted C. articulata populations using seedlings transplanted from nurserygrown seeds. Phenology of 20 Mabira forest plants was monitored with the aim of collecting seeds. One hundred and fifty-six ripe fruits were collected, and 233 of the extracted seeds were planted in pots in a nursery during January-March 2019. During November-December 2019, seedlings were planted near the sites from which fruits were collected. Seed germination success rate was $89 \%$, and fifteen months after transplanting, in situ survival was $100 \%$. These results suggest that depleted C. articulata populations may be restored in situ using nursery-grown seeds.

\section{Introduction}

Citropsis articulata (Willd. ex Spreng.) Swingle \& M. Kellerm (Family Rutaceae) is an evergreen shrub or small tree of rainforest and dry semi-deciduous forest. Mature plants range from 2.5-7 $\mathrm{m}$ in height. Also known as the African or Uganda cherry orange, it is native to tropical Africa, from Ghana to DR Congo and Uganda. The branches have thorns 5 $-25 \mathrm{~mm}$ long. It is sometimes harvested from the wild for its edible fruit and medicinal uses (Tropical Plants Database) [1].

The species is reported to be popular in Uganda for reproductive medicine [2]. Because the root is ground into a powder imagined to serve as a male aphrodisiac, "harvesting" can often involve uprooting and thus killing the tree. As a result of overharvesting, its populations are considered to be threatened in the wild [2].

The reported reproductive effects of $C$. articulata have drawn a raft of studies on its medicinal applications [3-8]. However, the threat of overharvest has drawn less attention $[9,10]$ and possible methods of in situ restoration have not yet been investigated.

The objective of this study was to assess the potential for use of seeds in enhancement of the wild populations. There is currently no information available in the literature on propagation of the species other than a note in the Tropical Plants Database (Loc. cit) that seeds are rather slow to germinate but plants usually come relatively true to their parent and a note in Kamatenesi-Mugisha and Oryem-Origa [2] that their propagation is ongoing. This study is a scaled up version of a preliminary observation made during 2017 and 2018 when four seeds from one fruit were planted in a nursery and then transplanted to natural forest where postplanting survival of the seedlings was monitored. All seeds germinated, and seedlings were alive at least 15 months after germination. This study is an upgradation of that experiment and tries to answer the following questions. (i) What is the germination success rate of the seeds when planted in a nursery? (ii) What proportion of the seedlings survives when transplanted in their natural habitat?

\section{Materials and Methods}

This study was conducted in Mabira Central Forest Reserve in Uganda. It is part of wider ongoing effort to document and address the reserve's restoration needs $[9,11]$. 


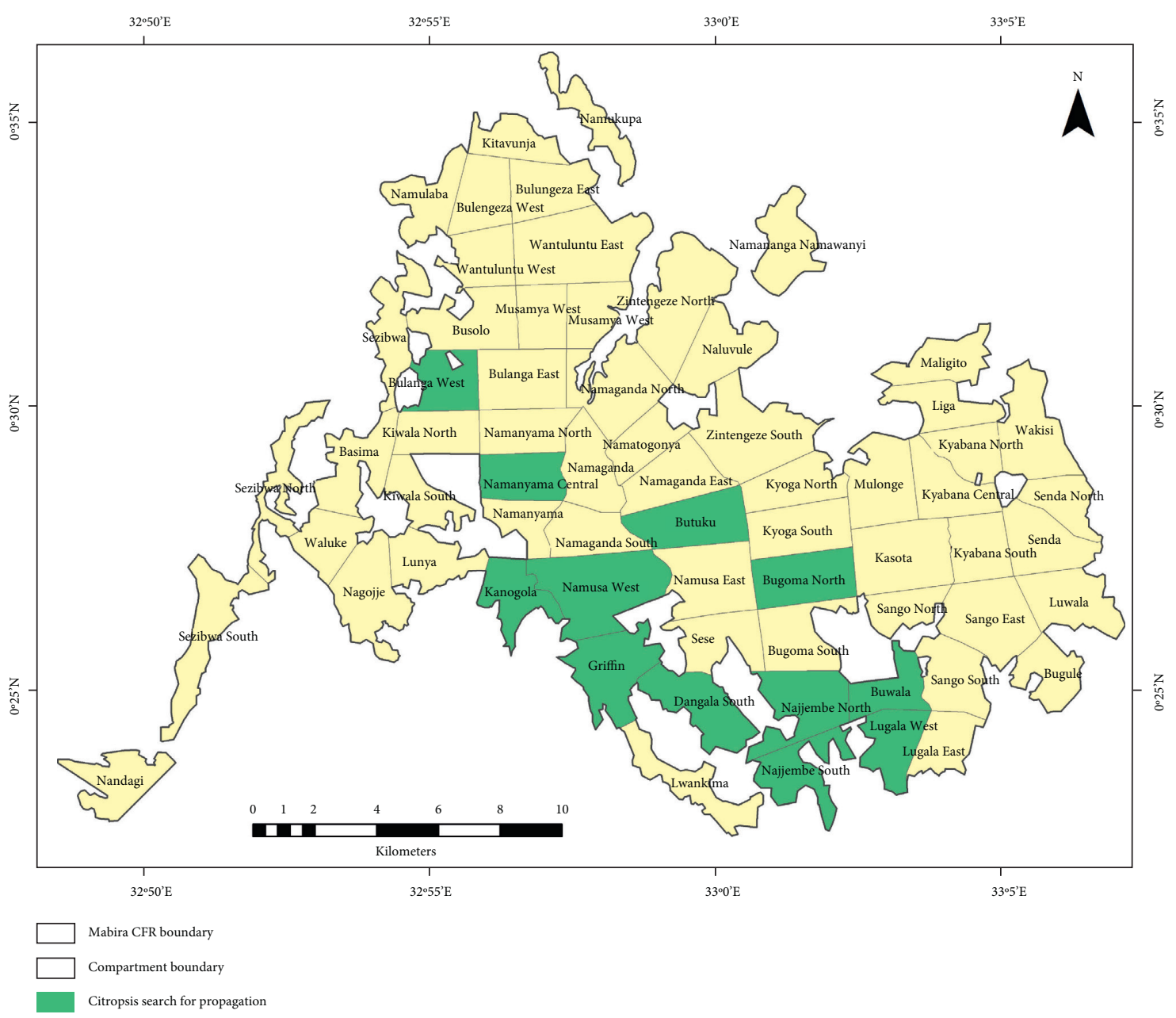

Figure 1: Map of Mabira Central Forest Reserve showing areas (shaded green) of search of C. articulata.

As the fruiting periods were barely known, the plants occur in low density, and the fruits are rarely found on any given adult plant [9]; the first step was to design measures to ensure success of collecting the fruits when available. Twenty large, presumably mature individuals were identified in the southernmost areas of the reserve (Figure 1). Olupot and Sande [9] documented the highest density of the species in this location. These 20 individuals were then monitored on a bimonthly basis for leafing, flowering, and fruiting (Figure 2). These phenology follows were conducted from August 2018-March 2019. During the course of these observations, we noted substantial predation of the developing fruits by sympatric primates (redtailed monkeys (Cercopithecus ascanius) and grey-cheeked mangabeys (Lophocebus albigena ugandae)). To help protect the fruits from arboreal primates, we concealed them from above by camouflaging them with leaves (Figure 3).

Fruits were collected upon ripening as indicated by yellowing. Yellow and yellowing fruits were collected during December 2018-March 2019. Fruits that had not fully attained the yellow coloration at the time of collection were stored and covered under room temperature until they became fully yellow. Seeds were readily extracted from fully yellow fruits by a gentle squeeze which popped out seeds. The seeds were sorted to separate the potentially viable (rounded seeds) from the potentially nonviable (flattened and shriveled) seeds. Because such information is not available in the literature, some of the ripe fruits were dissected vertically and horizontally to measure lengths and diameters using a ruler.

After 4-5 days of storage in room temperature and away from direct sunlight, 233 potentially viable seeds were sown, one per pot, into pots with a top diameter of 5 inches. The pots were filled with soil collected from the forest floor. Care was taken to not expose the pots to too much rain and too much sunshine. Pots were monitored daily for seedling emergence. All the germinated seedlings were planted in the forest near the sites of fruit collection during November and December 2019 (Figure 4). A follow-up visit was made on $26^{\text {th }}$ February 2021 to determine post-planting in situ survival.

\section{Results}

Flowering and fruiting were observed during all the eight months of phenology monitoring. Peak flowering was recorded in January, and peak fruit ripening was recorded during February. Altogether, 156 fruits each with 0-4 seeds were collected, and 354 seeds were extracted.

Sixteen ripe or ripening fruits averaged $2.0 \mathrm{~cm}$ $(\mathrm{SD}=0.214)$ in length and $2.1 \mathrm{~cm}(\mathrm{SD}=0.211)$ in diameter. A 


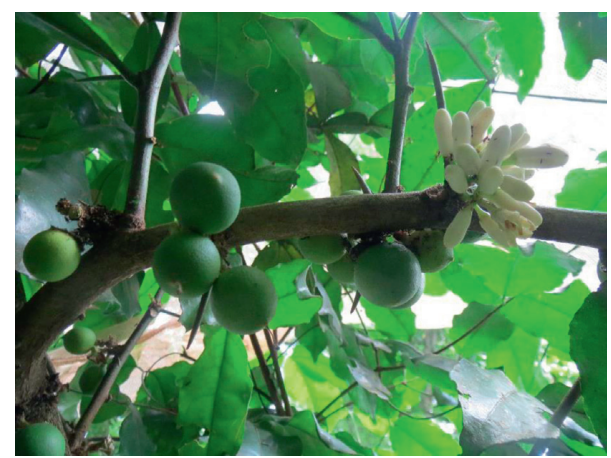

FIgURE 2: Flowers and unripe fruits of C. articulata.

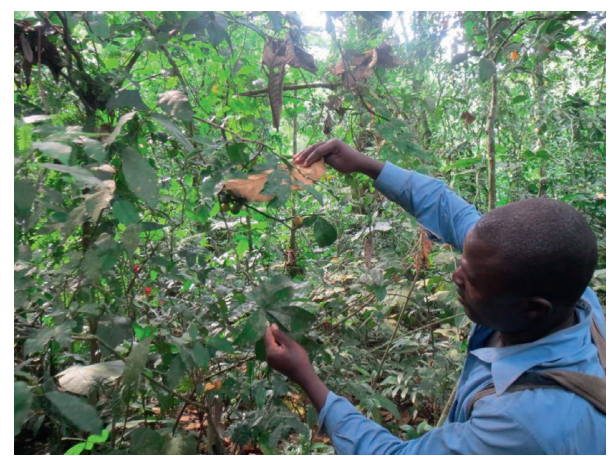

FIgURE 3: An illustration of how predation on monitored fruits was reduced. In this case, a leaf collected from the site was used to obscure sight of the fruits from above.

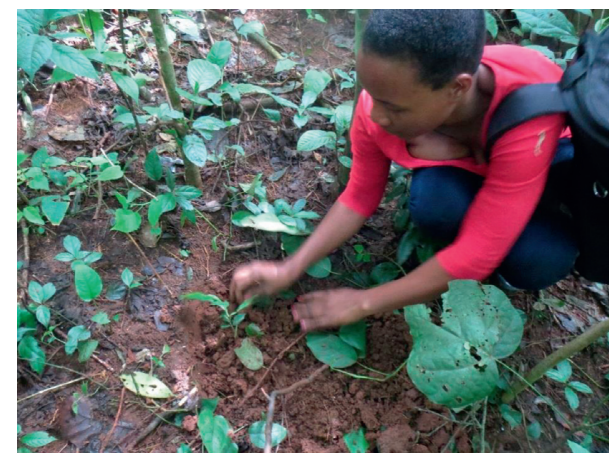

FIGURE 4: Seedling planting in the forest.

total of 233 seeds were sown. Out of these, $89 \%$ (208) germinated. The duration from seed sowing to seedling emergence varied from 16-24 days (mean $\pm \mathrm{SD}=$ 20.954 $\pm 2.312, n=95$ ) (Figure 5).

Post-germination survival rates of the germinated seedlings were $100 \%$ within the nursery. A monitoring visit made 15 months after seedling planting in the forest determined that all the transplanted seedlings were surviving (e.g., Figure 6).

\section{Discussion}

The high germination and post-planting seedling survival rates suggest that restoration of impacted populations of the species using seeds is possible. By considering active restoration, rather than measures to enable natural regeneration, it is assumed that natural regeneration would take a very long time to recover the population of the species. This is because the "orange-like" characteristic of the fruit may not easily render itself to seed dispersal. It appears that the seeds can only disperse if a predator chances upon the rare ripe fruit and the mechanical handling causes the seeds to pop out or if the act of predation does not damage the seeds and the seeds are spit out. Another possibility is that the impact of a fall causes seed expulsion. Both of these scenarios look remote because as a result of flower and immature fruit abscission, as well as predation on raw fruits, very few fruits may reach the ripe stage. When the ripe fruit does fall, interception by vegetation and a cushioning effect of the leaf litter are likely to reduce impact of the drop to the extent that the seeds are not expelled. The low rate of natural seed dispersal and regeneration is suggested by the experience of Olupot and Sande [9] who rarely encountered seedlings underneath or away from the mature plants during their study.

Use of seed for enhancement of the population of this species rather than roots, stems, or other genetic material is recommended for two reasons. First is the sheer quantity of planting material made available by seeds. Second is the consideration of the need to maintain genetic diversity. Prevailing opinion is that if, as in this case, site degradation has not been severe, "local" and "diverse," seed sources are a logical starting point [12]. Use of seed can ensure that the restored population has the ability to evolve and recover from disturbances (e.g., [13]). Ability of populations to resist natural shocks when seeds are used for restoration has for example been demonstrated in 


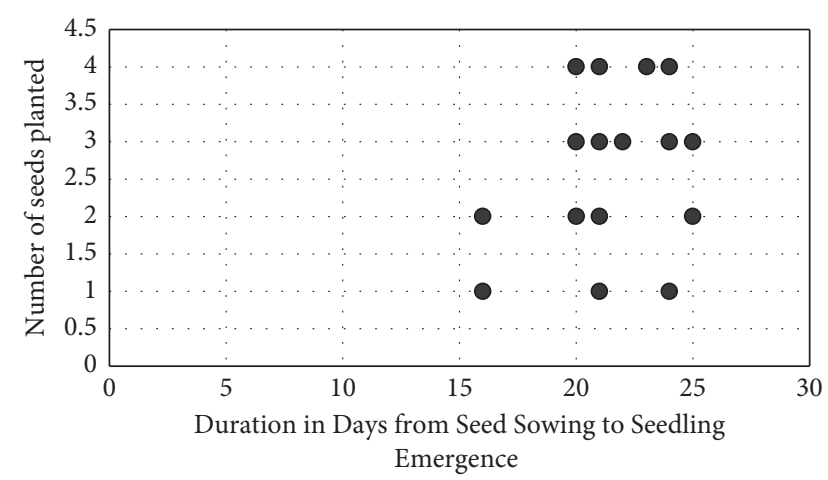

FIGURE 5: A plot of the distribution of number of seeds germinating against the number of days elapsed since seed sowing for 95 seeds. Size of blob corresponds to the number of seeds germinating with 1 and 4 being the minimum and maximum, respectively.

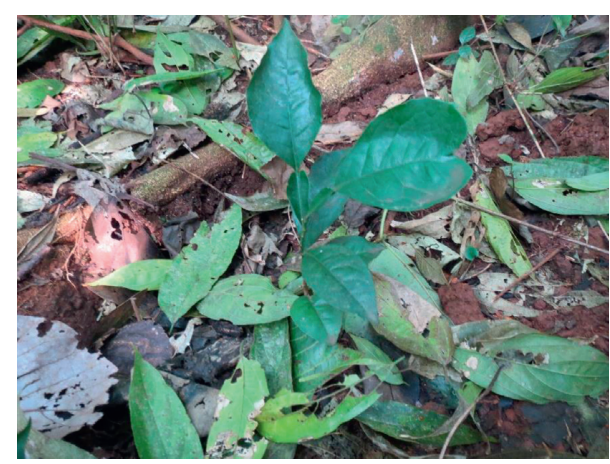

FIGURE 6: Seedling surviving in forest 15 months after planting.

seagrasses [14]. The study found that plants restored using seeds rather than adult plants resulted in a higher genetic diversity and a greater level of ecosystem resilience in the restored meadows.

\section{Conclusions}

This study demonstrates the feasibility of conserving C. articulata populations in situ, using nursery germination followed by transplantation to natural forest. It also suggests a possibly less cumbersome procedure that wild populations might be restored by planting seeds directly in appropriate forest sites. Assessing the success of this approach will require further experimentation together with detailed study of the species' ecology in the wild to guide choice of planting sites and seed spacing.

\section{Data Availability}

The datasets used in this study are available from the corresponding author upon request.

\section{Disclosure}

This study was implemented under a memorandum of understanding between the National Forestry Authority and Nature and Livelihoods.

\section{Conflicts of Interest}

The author has no conflicts of interest to declare.

\section{Acknowledgments}

I thank Deogratius Baliddawa and Samuel Kabugo for assistance in plant monitoring and fruit collection and Deogratius Baliddawa for nursery support. This study was supported by the MacArthur Foundation (grant no. 14106423-000). Production of this publication was made possible by financial support from Environmental Education and Conservation Global.

\section{References}

[1] Tropical Plants Database, "Ken fern. tropical.theferns.info," 2021, https://tropical.theferns.info/viewtropical.php?id=Citro psis+articulata.

[2] M. Kamatenesi-Mugisha and H. Oryem-Origa, "Traditional herbal remedies used in the management of sexual impotence and erectile dysfunction in western Uganda," African Health Sciences, vol. 5, pp. 40-49, 2005.

[3] L. Damien, S. Prado, D. Kamoga, J. Kasenene, and B. Bodo, "Structure and in vitro antiparasitic activity of constituents of Citropsis articulata root bark," Journal of Natural Products, vol. 74, pp. 2286-2289, 2011.

[4] N. J. Gakunga, K. Mugisha, D. Owiny, and P. Waako, "Effects of crude aqueous leaf extracts of Citropsis articulata and Mystroxylon aethiopicum on sex hormone levels in male albino rats," International Journal of Pharmaceutical Science Invention, vol. 3, pp. 5-17, 2014.

[5] P. Vudriko, M. Baru, J. Kateregga, and J. Ndukui, "Crude ethanolic leaf extracts of Citropsis articulata: a potential phytomedicine for treatment of male erectile dysfunction associated with testosterone deficiency," International Journal of Basic \& Clinical Pharmacology, vol. 3, no. 1, pp. 120-323, 2014.

[6] J. Oloro, P. E. Alele, M. Amanya, J. K. Tanayen, J. O. C. Ezeonwumelu, and A. G. Agaba, "Effects of aqueous root bark extract of Citropsis articulata (swingle \& kellerman) on sexual function in male rats," African Journal of Pharmacy and Pharmacology, vol. 9, pp. 723-729, 2015.

[7] Y. L. Kenneth, "Effect of the methanolic extract of fruit bark of Citropsis articulata on the testes of male wistar rats," Journal of Cytology \& Histology, vol. 7, no. 4(Suppl), 2016.

[8] E. D. Eze, P. Nganda, O. A. Okpanachi, O. S. Sheu, and E. T. Ayikobua, "Effect of aqueous root extract of Citropsis articulata on the levels of CAMP and cGMP-dependent protein kinase-I in penile tissue of New Zealand white male rabbits," American Journal of Medicine and Medical Sciences, vol. 7, pp. 345-349, 2017.

[9] W. Olupot and E. Sande, "Evaluating the status of forest understory plants on high demand in an "open access" setting for restoration and community engagement," Heliyon, vol. 5, Article ID e01468, 2019.

[10] R. Wangalwa, E. A. Olet, G. Kagoro-Rugunda, C. U. Tolo, P. E. Ogwang, and B. Barasa, "Occurrence of Citropsis articulata in tropical forests in Uganda: implication for ex situ conservation," International Journal of Financial Research, vol. 2021, Article ID 5582461, 19 pages, 2021.

[11] E. Sande, S. Akoth, U. Rutazaana, and W. Olupot, "Status of nahan's partridge ptilopachus nahani (Dubois, 1905) (aves: 
galliformes: odontophoridae) in Uganda," Journal of Threatened Taxa, vol. 12, no. 15, pp. 17063-17076, 2020.

[12] V. J. Erickson and A. Halford, "Seed planning, sourcing, and procurement," Restoration Ecology, vol. 28, no. S3, pp. S219-S227, 2020.

[13] K. J. Vaughn, L. M. Porensky, M. L. Wilkerson et al., "Restoration ecology," Nature Education Knowledge, vol. 3, p. 66, 2010.

[14] L. Reynolds, M. Waycott, K. McGlathery, R. Orth, and J. Zieman, "Eelgrass restoration by seed maintains genetic diversity: case study from a coastal bay system," Marine Ecology Progress Series, vol. 448, pp. 223-233, 2012. 